Note

\title{
PERFORMANCE OF ADVANCED GENERATION FROM A HYBRID JAPANESE CUCUMBER
}

\author{
Victoria Rossmary Santacruz Oviedo ${ }^{1}$; Amanda Regina Godoy ${ }^{2}$; Antonio Ismael Inácio \\ $\operatorname{Cardoso}^{3 *}$ \\ ${ }^{I}$ USP/ESALQ - Programa de Pós-Graduação em Fitotecnia. \\ ${ }_{3}^{2}$ UNESP/FCA - Programa de Pós-Graduação em Horticultura. \\ ${ }^{3}$ UNESP/FCA - Depto. de Produção Vegetal, C.P. 237 - 18603-970 - Botucatu, SP - Brasil. \\ *Corresponding author <ismaeldh@fca.unesp.br>
}

\begin{abstract}
Inbreeding reduces the vigor in plants as a result of a decrease in the proportion of heterozygous loci. However, the influence of inbreeding is different among the species. The objective of this work was to evaluate the inbreeding depression in a cucumber Japanese population. An $\mathrm{F}_{2}$ population was obtained from a commercial hybrid (Natsu suzumi), which was considered as $S_{0}^{2}$ population. $\mathrm{S}_{1} \mathrm{~S}_{2}, \mathrm{~S}_{3}, \mathrm{~S}_{4}$ and $\mathrm{S}_{5}$ progenies were obtained by the 'Single Seed Descent' methodology. A complete blocks design with seven treatments (different generations of self pollination $-\mathrm{S}_{0}$ to $\mathrm{S}_{5}$ and the hybrid Natsu suzumi), and six replications of five plants per plot was used in protected cultivation from Aug. 21 to Nov. 29, 2002. Number of leaves, length of the main stem, number and weight of fruits (total and commercial) number of nodes and vines percentage were evaluated. For most of the traits appraised differences were not observed among populations showing that there was no loss of vigor due to inbreeding in this population.
\end{abstract}

Key words: Cucumis sativus L., breeding, heterosis

\section{COMPORTAMENTO DE GERAÇÕES AVANÇADAS DE UM HÍBRIDO DE PEPINO JAPONÊS}

\begin{abstract}
RESUMO: A endogamia reduz o vigor em plantas pela diminuição da proporção de loci heterozigotos. Entretanto, a influência da endogamia é diferente entre as espécies. O objetivo deste trabalho foi avaliar a depressão causada por endogamia em uma população de pepino do tipo japonês. A partir do intercruzamento entre plantas do híbrido Natsu suzumi foi obtida a geração $\mathrm{F}_{2}$, considerada como população $S_{0}$. Obtiveram-se progênies $S_{1}, S_{2}, S_{3}, S_{4}$ e $S_{5}$, através de autofecundações sucessivas pelo método do SSD ('Single Seed Descent'). Foram sete tratamentos (híbrido Natsu suzumi, populações $\mathrm{S}_{0}$ a $\mathrm{S}_{5}$ ) e o delineamento experimental foi em blocos ao acaso, com seis repetições e cinco plantas por parcela cultivadas em ambiente protegido de 21/08/2002 à 29/11/2002. Foram avaliados o número de folhas, semanalmente, o número e a massa de frutos, total e comercial, número de nós e porcentagem de nós com brotações laterais. Na comparação entre as populações $S_{0}$ a $S_{5}$ não foram observadas diferenças para todas as características avaliadas demonstrando não haver perda de vigor por endogamia nesta população.

Palavras-chave: Cucumis sativus L., melhoramento, heterose
\end{abstract}

\section{INTRODUCTION}

Inbreeding reduces the vigor in plants as a result of a decrease in the proportion of heterozygous loci (Hayes et al., 2004). Although the inbreeding depression is a consequence of an increase of the homozygous, its magnitude depends on number and types of deleterious genes, exposed to conditions of homozygosis (Charlesworth \& Charlesworth, 1979). The influence of inbreeding is thoroughly different among species (Byers \& Waller, 1999; Husband \&
Schemske, 1996). Most of the superior plants, mainly cross-pollinated, show a depression in larger or smaller degree as a consequence of the inbreeding. However, some species that are naturally self-pollinated do not show this depression. Cucurbits are cross-pollinated, but they are examples of species in which some lines seem to lose little vigor due to inbreeding (Allard, 1978; Withaker \& Robinson, 1986).

Inbred lines have been developed in cucumber, pumpkin, melon and watermelon without loss of vigor 
(Robinson, 1999). Inbreeding depression is not an important factor for hybrid seed production in cucurbits.

Nowadays, the use of hybrid seeds in vegetables is common in developed and in some developing countries. However, most of Japanese cucumber hybrids used in Brazil are matter of concern since represent high annual expenses in seed importation (Lopes, 1991). In spite of the absence of loss of vigor, the use of cucumber hybrid is very common due to heterosis. But lines can produce as well as hybrids and they can be used directly, because lack of inbreeding depression (Cramer \& Whenner, 1999; Robinson, 1999). Researches are contradictory in relation to loss of vigor in cucumber due to inbreeding depression.

The objective of this study was to evaluate the possible existence of inbreeding depression in a Japanese cucumber population.

\section{MATERIAL AND METHODS}

The experiment was carried out in São Manuel, State of São Paulo, Brazil $\left(48^{\circ} 34^{\prime} \mathrm{W}, 2^{\circ} 44^{\circ} \mathrm{S}\right.$; mean altitude $750 \mathrm{~m}$ ) at protected cultivation. Populations were obtained from the $\mathrm{F}_{1}$ commercial hybrid Natsu suzumi (Takki company) a Japanese type tolerant to powdery mildew recommended to protected cultivation. After randomly crossing $F_{1}$ plants, the $F_{2}$ generation was obtained. This was considered as the initial population, called the $S_{0}$ population. About 80 plants of this $F_{2}$ population were self-pollinated in order to obtain the $\mathrm{S}_{1}, \mathrm{~S}_{2}, \mathrm{~S}_{3}, \mathrm{~S}_{4}$ and $\mathrm{S}_{5}$ progenies, through successive self-pollination using the SSD method ("Single Seed Descent"), proposed by Brim (1966). Population $\mathrm{S}_{1}$ was obtained by mixing seeds of progenies $\mathrm{S}_{1}$, in other words, the $S_{1}$ population was a random sample of all $\mathrm{S}_{1}$ progenies, and each progeny participated with the same number of seeds. The same procedure was performed for the other generations to obtain populations $\mathrm{S}_{2}, \mathrm{~S}_{3}, \mathrm{~S}_{4}$ and $\mathrm{S}_{5}$. Self pollinations were controlled according to Lower \& Edwards (1986). Seeds were stored in a chamber with $40 \%$ relative humidity and temperature of $20^{\circ} \mathrm{C}$.

The commercial hybrid Natsu suzumi was used as a control for fruit type and potential yield. Seven treatments (hybrid Natsu suzumi and the six derived populations: $\mathrm{F}_{2}=\mathrm{S}_{0}, \mathrm{~S}_{1}, \mathrm{~S}_{2}, \mathrm{~S}_{3}, \mathrm{~S}_{4}, \mathrm{~S}_{5}$ ) were planted according a randomized block designed with six replications of five plants per plot.

Soil analysis was performed and fertilization was in agreement to the recommendation by Raij et al. (1996) and drip irrigation was used. Seedlings were produced in trays of expanded polystyrene of 128 cells, for subsequent transplantation to the definitive place.
The spacing was $1.0 \mathrm{~m}$ between rows and $0.5 \mathrm{~m}$ between plants. Seeding was made on 21/august/02 and the transplantation on 12/september/02.

Plants were grown in a vertical position and the stems and flowers were removed until the fifth node of the main stem. The apical meristem of the plant was removed when reaching an approximate height of $1.80 \mathrm{~m}$. Harvesting started 34 days after the transplant and lasted for 43 days, with two-day intervals; all fruits with approximately $20 \mathrm{~cm}$ length were harvested. The total cycle was 97 days, starting from the sowing. In each harvest, the fruits were classified into commercial (fruits without apparent and straight defects) and non commercial. In this way, the total production of fruits was obtained, in number and weight, per plant, as well as the production of commercial fruits, number and weight, the rate of commercial fruits and the average weight of commercial fruit. The number of days from sowing to harvest was also recorded. Determination of number of leaves per plant was recorded weekly, and at the end of the cycle the number and the percentage of nodes with lateral stems were also determined.

Variance analysis was accomplished and the means were compared by the Tukey test (PL 0.05).

\section{RESULTS AND DISCUSSION}

Differences were not observed among the treatments for number of leaves per plant in all evaluations along the cycle. The plants showed a slow development until the third week after the transplant, when a fast vegetative development occurred. Between the $26^{\text {th }}$ and $34^{\text {th }}$ days, after transplant, a medium increase of approximately 1.0 new leaf a day was obtained. Therefore, the successive self-pollination did not affect the vegetative development of the plants comparatively to the original $F_{1}$ hybrid.

Differences were also not observed among the treatments from the beginning of the crop harvesting, with an average of 58 days after the sowing for all levels of inbreeding studied $\left(\mathrm{F}_{2}-\mathrm{S}_{5}\right)$ and the commercial hybrid (Table 1). An average of 35.5 days was obtained after the transplant for the crop, a value similar to the 33 days obtained by Blanco et al. (2002). On the other hand, Cardoso \& Silva (2003), studying a different japanese hybrid, obtained 72 days after the sowing in autumn - winter cultivation. However, for the summer cultivation the harvest began 47 days after the sowing. In this way, the inbred populations were as precocious as the original hybrid, what have not been reported in the several heterosis papers for precocity in cucumber (Wehner \& Miller, 1985; Filgueira et al., 1986; Cui et al., 1992; Viggiano, 1994; Li et al., 1995). 
Table 1 - Number of days (from the sowing) for crop first harvesting (NDH), number of total fruits (NTF), number of commercial fruits (NCF), total weight (TMP), and commercial weight per plant (CMP), percentage of commercial fruits $(\mathrm{CF})$, average weigth of commercial fruits $(\mathrm{MCF})$ in cucumber populations with levels of inbreeding. SãoManuel/SP.

\begin{tabular}{lccccccc}
\hline Treatments & NDH & NTF & NCF & TMP & CMP & CF & MCF \\
\hline Natsu suzumi & $58.2 \mathrm{a}$ & $21.6 \mathrm{a}$ & $13.6 \mathrm{a}$ & $2298.8 \mathrm{a}$ & $1625.1 \mathrm{a}$ & $63.1 \mathrm{a}$ & $117.6 \mathrm{a}$ \\
$\mathrm{F}_{2}=\mathrm{S}_{0}$ & $58.8 \mathrm{a}$ & $20.2 \mathrm{ab}$ & $14.0 \mathrm{a}$ & $2237.0 \mathrm{a}$ & $1679.3 \mathrm{a}$ & $67.4 \mathrm{a}$ & $121.4 \mathrm{a}$ \\
$\mathrm{S}_{1}$ & $57.5 \mathrm{a}$ & $15.6 \mathrm{ab}$ & $10.7 \mathrm{a}$ & $1676.6 \mathrm{a}$ & $1256.7 \mathrm{a}$ & $68.9 \mathrm{a}$ & $117.9 \mathrm{a}$ \\
$\mathrm{S}_{2}$ & $57.2 \mathrm{a}$ & $17.2 \mathrm{ab}$ & $10.9 \mathrm{a}$ & $1878.4 \mathrm{a}$ & $1324.4 \mathrm{a}$ & $62.6 \mathrm{a}$ & $122.2 \mathrm{a}$ \\
$\mathrm{S}_{3}$ & $57.9 \mathrm{a}$ & $15.6 \mathrm{ab}$ & $9.9 \mathrm{a}$ & $1691.1 \mathrm{a}$ & $1178.3 \mathrm{a}$ & $62.9 \mathrm{a}$ & $117.5 \mathrm{a}$ \\
$\mathrm{S}_{4}$ & $57.3 \mathrm{a}$ & $19.9 \mathrm{ab}$ & $12.9 \mathrm{a}$ & $2408.4 \mathrm{a}$ & $1556.9 \mathrm{a}$ & $64.9 \mathrm{a}$ & $120.9 \mathrm{a}$ \\
$\mathrm{S}_{5}$ & $58.5 \mathrm{a}$ & $14.3 \mathrm{~b}$ & $8.9 \mathrm{a}$ & $1551.5 \mathrm{a}$ & $1066.9 \mathrm{a}$ & $61.9 \mathrm{a}$ & $118.9 \mathrm{a}$ \\
\hline Means $\left(\mathrm{S}_{0}-\mathrm{S}_{5}\right)$ & 57.9 & 17.1 & 11.2 & 1907.2 & 1343.8 & 64.8 & 119.8 \\
\hline C.V $(\%)$ & 2.12 & 9.8 & 14.2 & 29.9 & 30.8 & 6.2 & 10.2 \\
\hline TSM1 & $0.01^{\text {ns }}$ & $0.60^{*}$ & $0.45^{\text {ns }}$ & $718727^{\mathrm{ns}}$ & $337883^{\text {ns }}$ & $0.16^{\text {ns }}$ & $23.1^{\text {ns }}$ \\
\hline
\end{tabular}

Means followed by the same letter, in the columns, do not differ by the Tukey test $(5 \%) .{ }^{1} \mathrm{TSM}-$ treatment square mean: ns, $*, * *=$ not significant at $5 \%$ and $1 \%$, respectively, by $\mathrm{F}$ test.

Differences were also not observed for number of commercial fruits, total weight and commercial weight per plant (Table 1). For number of total fruits, the commercial hybrid was superior to generation $\mathrm{S}_{5}$. However, no differences were obtained for this characteristic among the inbred populations $\left(\mathrm{S}_{0}-\mathrm{S}_{5}\right)$, demonstrating the absence of loss of vigor with the successive inbreeding generations. It is pointed out, however, that the means of populations with different degrees of inbreeding were evaluated and that the lines obtained after a certain number of generations of selfpollination can present results with different relationship to the loss of vigor (Maluf, 2001).

The evaluated populations representing a mixture of progenies, on average, presented reduction in the total fruit number per plant after five generations of self-pollination in comparison with the commercial hybrid. However, progenies can be found where there is no loss in comparison to the original population without inbreeding. Besides, progenies with low vigor can generate populations or hybrids with high vigor after recombination to obtain heterozygosity (Maluf, 2001).

The values obtained (Table 1) are not similar to those reported in the literature. Cardoso \& Silva (2003) obtained 33 and 20 fruits/plant in the evaluation of hybrids of Japanese cucumber in winter and summer cultivation, respectively. Fernandes et al. (2002) obtained $920 \mathrm{~g}$ per plant in nutrient solution. On the other hand, Blanco et al. (2002) obtained a total production of 33.0 fruits per plant and 29.1 commercial fruits in cucumber grafted under protected cultivation irrigated with saline water. There was no difference in the commercial fruit rates (Table 1), so, the successive self-pollinations did not affect fruit quality. For average fruit weight, no differences were obtained, probably because the harvesting point was approximately the same for all the materials (fruits with about $20 \mathrm{~cm}$ of length).

Furthermore, differences were not observed among the treatments when the number of nodes (20.0 in average) and its percentage with lateral stems (17.3\% in average) are considered. Cardoso \& Silva (2003) obtained, on average, larger production in the hybrid (Tsuyataro, from Takii company) with larger percentage of lateral stems.

On average, the absence of loss of vigor with the successive self-pollinations was noticed, in several reports in cucumber (Jenkins Jr., 1942; Rubino \& Wehner, 1986; Cramer \& Wehner, 1999) as in other cucurbits (Allard, 1978; Withaker \& Robinson, 1986; Robinson, 1999; Cardoso, 2004) in spite of other several reports of significant heterosis in hybrid $\mathrm{F}_{1}$ in cucumber (Wehner \& Miller, 1985; Filgueira et al., 1986; Cui et al., 1992; Viggiano, 1994; Li et al., 1995). Inbreeding depression depends on the allelic frequency and on the dominance effects (Falconer, 1989). Therefore, there is not loss of vigor for $F_{1}$ hybrid with large heterozigosis in absence of dominance effects. Therefore, in this population, lines can be used like open pollinated cultivars as productive as the hybrids and with the same uniformity level $\left(\mathrm{S}_{5}\right.$ lines) being less expensive for the producer, in agreement with Robinson (1999).

The absence of loss of vigor for inbreeding in this population can be due to: i) the original population is not a hybrid as mentioned by the company or 
the parental lines are closely related and, therefore, there is no genetic segregation for the evaluated traits; ii) the absence of dominance effects by heterozygosis in the hybrid; iii) the cultural practices - pruning, blunt and harvesting of immature fruits - limit the development of the plants and can impose a production limit reached by all populations.

\section{REFERENCES}

ALlARD, R.W. Principios de la mejora genética de las plantas. Barcelona: Omega, 1978. 500p.

BLANCO, F.F.; FOLEGATTI, M.V.; NOGUEIRA, M.C.S. Fertirrigação com água salina e seus efeitos na produção de pepino enxertado cultivado em ambiente protegido. Horticultura Brasileira, v.20, p.442-446, 2002.

BRIM, C.A. A modified pedigree method of selection in soybeans. Crop Science, v.6, p.220, 1966.

BYERS, D.L.; WALLER, D.M. Do plant populations purge their genetic load? Effects of population size and mating history on inbreeding depression. Annual Review of Ecology and Systematics, v.30, p.479-513, 1999.

CARDOSO, A.I.I. Depression by inbreeding after four sucessive self-pollination squash generations. Scientia Agrícola, v.61, p.224-227, 2004.

CARDOSO, A.I.I.; SILVA, N. Avaliação de híbridos de pepino do tipo japonês sob ambiente protegido em duas épocas de cultivo. Horticultura Brasileira, v.21, p.170-175, 2003.

CHARLESWORTH, D.; CHARLESWORTH, B. The evolutionary genetics of sexual systems in flowering plants. Proceedings of the Royal Society, v.205, p.513-530, 1979.

CRAMER, C.S.; WEHNER, T.C. Little heterosis for yield and yield components in hybrids of six cucumber inbreeds. Euphytica, v.110, p.99-108, 1999.

CUI, H.W.; QI, Y.T.; LIU, J.H.; REN, Z.B. Correlation between parents and $\mathrm{F}_{1}$ progeny in earliness heterosis and the estimation of traits limits of parents. Report Cucurbit Genetics Cooperative, v.15, p.13-16, 1992.

FALCONER, D.S. Introduction to quantitative genetics. New York: Longman, 1989. 438p.

FERNANDES, A.A.; MARTINEZ, H.E.P.; OLIVEIRA, L.R. Produtividade, qualidade dos frutos e estado nutricional de plantas de pepino, cultivadas em hidroponia, em função de fontes de nutrientes. Horticultura Brasileira, v.20, p.571-575, 2002.
FILGUEIRA，F.A.R.; GIORDANO, L.B; FERREIRA，P.E.; VECCHIA, P.T.D. Avaliação de híbridos $\mathrm{F}_{1}$ de pepino do tipo caipira. Horticultura Brasileira, v.4, p.17-20, 1986.

HAYES, C.N.; WINSOR, J.A.; STEPHENSON, A.G. Environmental variation influences the magnitude of inbreeding depression in Cucurbita pepo ssp. texana (Cucurbitaceae). Journal of Evolutionary Biology, v.18, p.147, 2004.

HUSBAND, B.C.; SCHEMSKE, D.W. Evolution of the magnitude and timing of inbreeding depression in plants. Evolution, v 50, p.54-70, 1996.

JENKINS JR., J.M. Natural self-pollination in cucumbers. Proceedings of the American Society for Horticultural Science, v.40, p.411- 412, 1942.

LI, J.W.; LI, J.W.; WEI, Z.D. Genetic analysis for major agronomic characters in cucumber (Cucumis sativus L.). Acta Horticulturae, p.388-391, 1995.

LOPES, J.F.I. Palestra de abertura do Simpósio Brasileiro sobre Cucurbitáceas. Horticultura Brasileira, v.9, p.98-99, 1991.

LOWER, R.L.; EDWARDS, M.D. Cucumber breeding. In: BASSET, M.J., (Ed.) Breeding vegetable crops. Westport: Avi, 1986. p. $173-207$.

MALUF, W.R. Heterose e emprego de híbridos $F_{1}$ em hortaliças. In: NASS, L.L.; VALOIS, A.C.C.; MELO, I.S.; VALADARESINGLIS, M.C. (Ed.) Recursos genéticos e melhoramento: plantas. Rondonópolis: Fundação MT, 2001. p.237-356.

RAIJ, B. van.; CANTARELLA, H.; QUAGGIO, J.A.; FURLANI, A.M.C. Recomendações de adubação e calagem para o Estado de São Paulo. Campinas: Instituto Agronômico, 1996. $285 \mathrm{p}$.

ROBINSON, R.W. Rationale and methods for producing hybrid cucurbit seed. Journal of New Seeds, v.1, p.1-47, 1999.

RUBINO, D.B.; WEHNER, T.C. Effect of inbreeding on horticultural perfomance of lines developed from a openpollinated pickling cucumber population. Euphytica, v.35, p.459-464, 1986.

VIGGIANO, J. Hortaliças: cultivares e sementes. Horticultura Brasileira, v.12, p.252-254, 1994.

WEHNER, T.C.; MILLER, C.H. Effect of gynoecious expression on yield and earliness of a fresh-market cucumber hybrid. Journal of the American Society for Horticultural Science, v.110, p.464-466, 1985.

WITHAKER, T.W.; ROBINSON, R.W. Squash breeding. In: BASSET, M.J. (Ed.) Vegetable breeding. Westport: AVI, 1986. p.209242.

Received February 17, 2006

Accepted February 08, 2008 